\title{
Problems of Health Insurance Coverage and Health Care in the United States: Public and Private Solution Strategies'
}

\author{
Problemas de Cobertura de Seguridade em Saúde e Serviços nos \\ Estados Unidos da América: Estratégias para Soluções Públicas e \\ Privadas
}

\section{E. Richard Brown ${ }^{2}$}

BROWN, E. R Problems of Health Insurance Coverage and Health Care in the United States: Public and Private Solution Strategies. Cad. Saúde Públ., Rio de Janeiro, 8 (3): 270-286, julset, 1992.

A nearly universal consensus has developed in the United States that the current health care financing system is a failure. The system has been unable to control the continuing rapid rise in health care costs (by far, the highest in the world), and it has been unable to stem the growing population that has no health insurance coverage (at least 36 million people). There is nearly universal political agreement that government must provide health insurance to a far greater share of the population than ever before. The political debate now focuses on whether this expanded government role should supplement the private insurance system with an enlarged public program covering those left out of private insurance coverage, or replace private insurance with a universal government health insurance program covering the entire population.

Keywords: Health Insurance; Health Care Costs; National Health Insurance; Health Services Financing

\section{INTRODUCTION}

Despite the apparent attraction that many nations find in proposals to privatize their largely public systems for financing health care, the United States is moving in the opposite direction. In almost all OECD countries, public expenditures account for more than three-quarters of health spending, compared to only about 40 percent in the United States (Schieber \& Poullier, 1989). There now is nearly universal consensus in the United States that the current, largely private bealth care financing system is a failure. This view is shared by nine out of ten Americans, including the same proportions of

\footnotetext{
' Based on a paper presented at a conference of the Pan American Health Organization, Quebec City, March 18-20, 1991.

${ }^{2}$ School of Public Health, University of California. 10833 Le Conte Avenue, Los Angeles, CA, 90024-1772, U.S.A.
}

the general public and the chief executive officers of the nation's largest corporations (Blendon et al., 1990).

In many countries debate centers on whether to privatize some or all of public health care insurance or national health service programs. In the United States, there is wide consensus that government must provide social insurance for health services to a far greater share of the population than ever before. The political debate focuses on whether this public insurance program should supplement an expanded private insurance system or replace private insurance. The public policy debate is between establishing a government-mandated system of employment-based health insurance, with an expanded public program covering those left out of private insurance coverage, or instead creating a universal national health insurance program, thus expanding government 
involvement to cover the entire population.

This growing demand for government intervention in health care is a direct result of two fundamental problems in health services financing that have plagued the United States during the 1980s and 1990s. One problem is the soaring cost for health care and for health insurance, a problem which the U.S. shares to some extent with most industrialized nations. A second problem is the growing number of people who are uninsured for health care expenses, a problem that, among the industrialized countries, is virtually unique to the United States and the way it finances health services. The combined pressure of these two forces has generated growing political support for broad reforms to solve these problems, and this political pressure is bringing the country to a critical choice point.

\section{HEALTH INSURANCE COVERAGE}

Most people in the United States have some type of health insurance coverage. Nearly the entire elderly population, 65 years of age or older, is covered by Medicare, a federal social insurance program that covers about half the health care costs of the elderly. To pay for some of the expenses that Medicare does not cover, most of these elderly persons also have private insurance or Medicaid, a welfare-based program that covers about half of the poorest population (mainly those who are eligible for federal public assistance).

\section{The Uninsured Population is Large and Growing}

Among the nonelderly population, however, coverage is much more variable, and many people have no protection at all against medical expenses. In 1989, 74 percent of the nonelderly population had private insurance coverage, including 64 percent who obtained their own employment-based health benefits or were covered through employment of a family member and another 10 percent who had privately purchased insurance coverage. Another 10 percent of the nonelderly population were covered by Medicaid, a federal-state welfare-related program that covers about half of the poor, or another public program (Figure 1) (Brown et al., 1991; unless otherwise noted, all data on health insurance coverage are taken from this report and additional analyses by the author).

But 17 percent of the nonelderly population, more than 35 million Americans, have no coverage of any kind - neither private insurance, nor Medicare, nor Medicaid, nor any other coverage. These people thus have no protection against the costs of medical care for themselves or their families.

The problem in some regions and states, especially the southern and southwestern states, is even more severe than for the country as a whole. In California, for example, 23 percent of the population under 65 years of age -5.9 million persons - are uninsured, and in Los Angeles County, one in every three nonelderly persons is without any coverage.

FIGURE 1. Distribution of Nonelderly Persons by Insurance Coverage and Source of Coverage, U.S., 1989

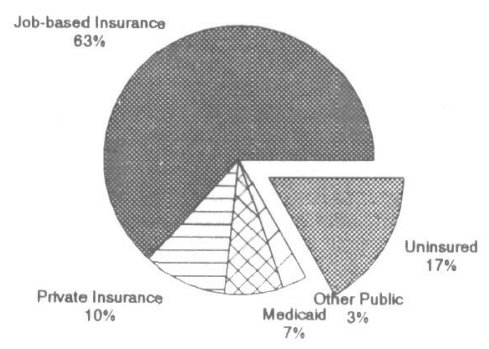




\section{The Uninsured are Disproportionately Young, Low-Income and Ethnic Minorities}

Nearly one-third of all the uninsured are children under the age of 18 , another 30 percent are between 18 and 29 years of age, and the rest are between 30 and 64 years of age (Figure 2). Young adults are most at risk for being uninsured; one in four persons 18-29 years of age is without any protection (in California, one in every three young adults is uninsured) (Figure 3).

FIGURE 2. Distribution of Uninsured Nonelderly Persons by Age, U.S., 1989

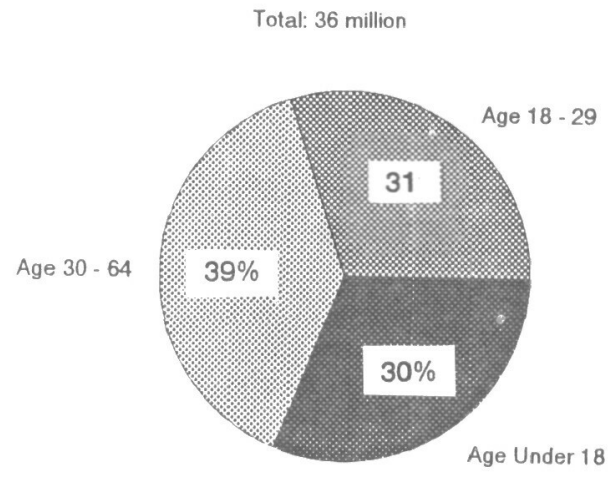

Source: March 1990 Current Population Survey, author's analysis
Nearly half ( 47 percent) of all the uninsured in the United States are poor or near-poor children and adults (in 1989, an annual income of about $\$ 19,000$ or less for a family of four). The relative poverty of the uninsured is important to the public policy debate because it is unlikely that most of the uninsured can afford to pay much, if anything, for their coverage. Nevertheless, a large proportion of the uninsured are not poor at all: 22 percent of the uninsured have family incomes in the upper half of the income distribution (about $\$ 38,000$ or more for a family of four).

Low-income persons are much more likely to be uninsured than the more affluent population. In 1989,35 percent of those with family incomes below the poverty line $(\$ 12,675$ for a family of four) and 36 percent of those just above the poverty line had no coverage, compared to 19 percent of those with family incomes between $150 \%$ and 299\% of the poverty line and just 7 percent of the more affluent population.

Thirty-eight percent of all nonelderly Latinos were uninsured in 1989 , the highest rate among all ethnic groups (three times as high as the rate for non-Latino whites). Although lower than the rate for Latinos, the proportions of uninsured blacks and Asians and other ethnic minority groups are two-thirds higher than the rate for non-Latino whites.

FIGURE 3. Percent Uninsured Nonelderly Persons by Age, U.S., 1989

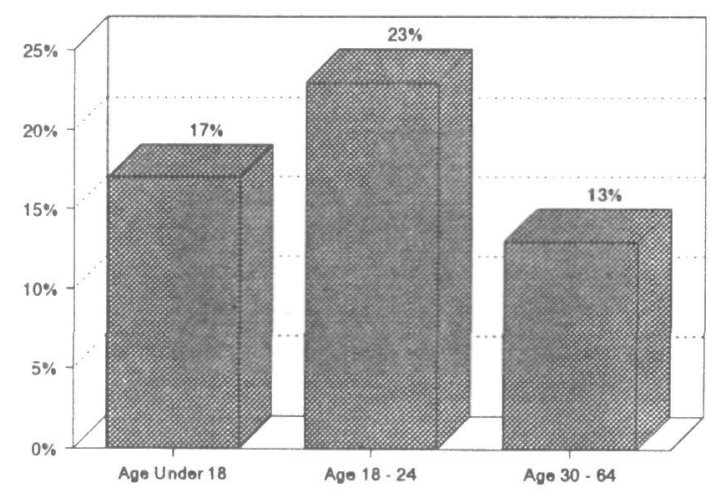

Source: March 1990 Current Population Survey, author's analysis 
Nearly Nine Out of Ten of the Uninsured are Workers or in Families Headed by a Worker

The uninsured are overwhelmingly workers and their families. Nearly 9 out of every 10 uninsured people -86 percent of the uninsured - are workers or in a family headed by at least one worker. In fact, 62 percent of the uninsured are full-time employees and their dependent spouses and children (the remaining 24 percent of the uninsured are part-time employees and the self-employed and their dependents) (Figure 4). Although most Americans gain access to health insurance as a fringe benefit of employment, the very large proportion of the uninsured who are working people and their families is clear evidence that employment-based private, voluntary health insurance inadequately covers even the working population.
Employees who work full time for the full year (at least 35 hours per week and at least 50 weeks a year) are more likely than other employees or self-employed workers to get health benefits through their own jobs. It is, therefore, not surprising that 74 percent of full-time full-year employees were covered by their employer's health plan in 1989. Another 16 percent received coverage through the insurance of another family member or some other source, but that left 10 percent who were completely uninsured. Full-time part-year employees and self-employed workers are two and one-half times as likely to be uninsured (Figure 5).

Low-income employees are far less likely to have health benefits through their employment and are far more likely to remain completely uninsured. Even among full-time full-year employees, the more people earn, up to about $\$ 35,000$ a year, the more likely they will be

FIGURE 4. Distribution of Uninsured Nonelderly Persons by Work Status of Adults in Household, U.S., 1989

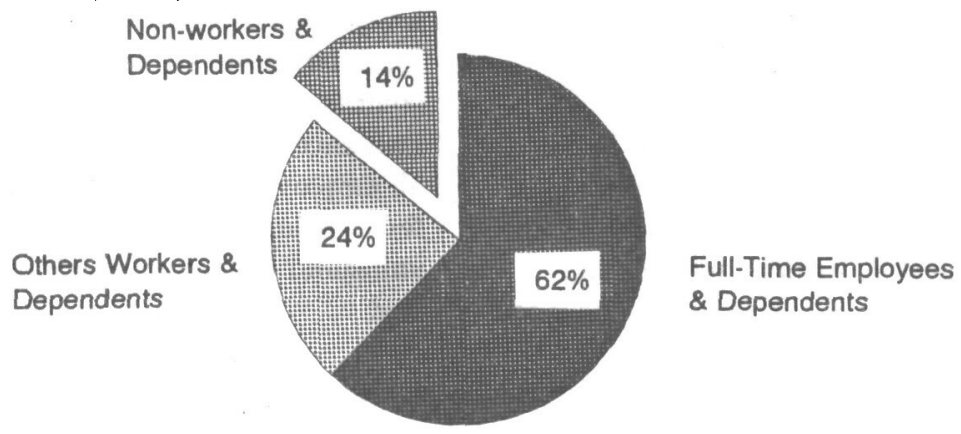

Source: March 1990 Current Population Survey, author's analysis

FIGURE 5. Percent Full-time Full-year Employees with Own Job-based Insurance and Uninsured, Ages 18-64, U.S., 1989

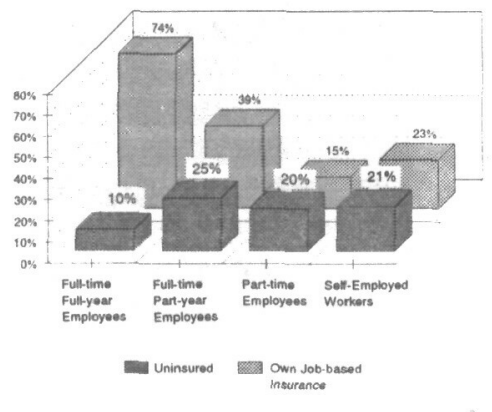


covered by their own or a family member's health benefits and the less likely they will be uninsured. More full-time full-year employees with personal incomes below $\$ 10,000$ are uninsured than are covered by employment-based health insurance.

A 1988 survey of homecare workers in Los Angeles, for example, found that 65 percent of these low-income service workers were uninsured. These workers, who earned $\$ 3.72$ per hour performing personal care services for elderly and disabled persons, received no health insurance through their jobs. Those who were not covered by the group health plan of a family member (many were single persons or single mothers) relied on taxpayer supported county hospitals for most of their care, although a small number were eligible for Medicaid (Service Employees International Union, 1988).

The proportion of full-time full-year employees who get job-based health benefits differs considerably by industry. Some industries - including transportation, cornmunications, and utilities; manufacturing; prcfessional services; financial services; wholesale trade; and public administration are far more likely to provide health benefits to at least their full-time full-year employees than are other industries - especially agriculture, forestry, fishing, and mining; construction; personal services; business and repair services; and retail trade (Figure 6). Unionized workers are much more likely than non-unionized workers to get job-based health insurance. Among unionized workers, 82 percent get their own health benefits, compared to 56 percent of those who are not covered by a union. Historically, the employment-based coverage, especially of blue-collar workers, was due to collective bargaining by unions on behalf of their members, accounting in part for the higher insurance coverage in the more heavily unionized industries. But with only 19 percent of American workers currently in unions or covered by a union contract, this factor has lost much of its influence for the working population as a whole.

Employees who work in small firms are much less likely to get employer-sponsored health benefits. Although 8 out of 10 full-time full-year employees in firms of 100 or more workers get their own benefits, fewer than 7 in 10 in firms of 25 to 99 workers get these benefits, and less than half in firms with fewer than 25 employees receive them (Figure 7). Small firms are one of the central contributing factors to the problem of lack of insurance coverage. Although 22 percent of all employees in the U.S. work in firms with fewer than 25 workers, 42 percent of all uninsured employees work in firms of this size.

FIGURE 6. Percent Full-time Full-year Employees with Own Job-based Insurance by Industry Ages 18-64, U.S., 1989

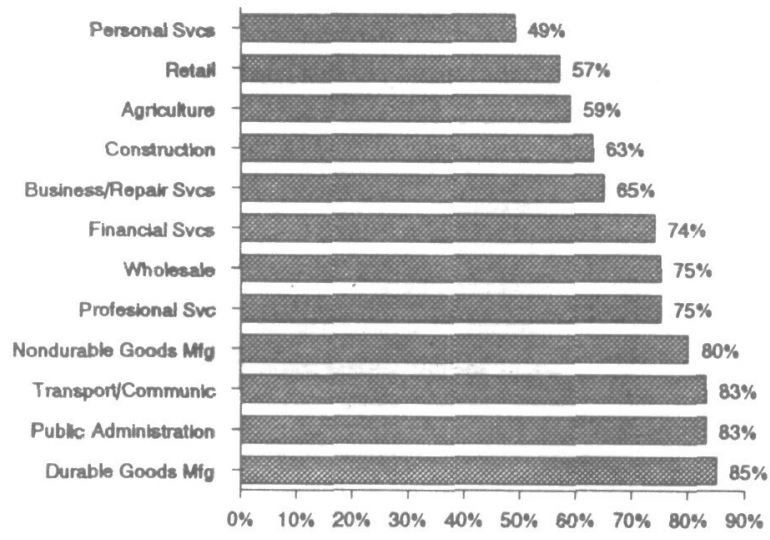


FIGURE 7. Percent Full-time Full-year Employees with Own Job-based Insurance and Uninsured by Firm Size, Ages 18-64, U.S., 1989

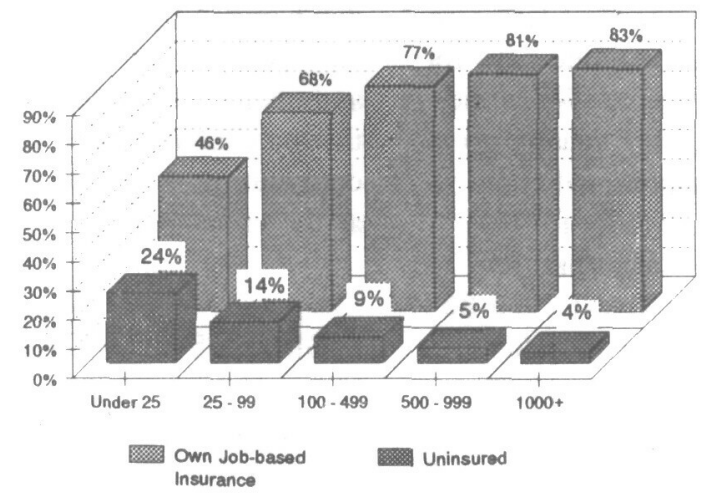

!Source: March 1990 Current Population Survey, author’s analysis

The decrease in employment-based insurance coverage among workers and their families is due in large part to a decline in jobs in manufacturing and other unionized, higher-wage sectors of the economy and an increase in employment in the retail and service sectors (Congressional Research Service, 1988). The shrinking of employment in industries that have traditionally provided health benefits, and the rapid growth of jobs in small retail and service firms, where low wages and seasonal employment are prevalent, has made increasing numbers of people question the continued reliance on private employment-based health insurance in the United States.

In addition to the population that is completely uninsured at any given time, a substantial portion of the population is inadequately covered by health insurance, leaving them exposed to major financial losses or debts due to expensive medical care. The most definitive analysis of this problem estimated that, including the inadequately insured and the completely uninsured, between 24 and 37 percent of the nonelderly population is underinsured against the predictable risks of large medical expenses. These included, in 1977, about 9 percent of the population who were uninsured throughout the year, more than another 9 percent who were uninsured part of the year, and at least another 5-18 percent with private insurance coverage that left them vulnerable to significant risks of spending at least 10 percent of their family income on medical expenses (Farley, 1985). It is a virtual certainty that the underinsured now represent considerably more than the one-quarter to one-third of the population they were a decade and a half ago.

\section{Why is the Growing Lack of Health Insurance a Problem?}

Several factors make the lack of health insurance a serious problem for the uninsured themselves and for health care providers, local governments, and employers who do provide health benefits. First, compared to people with health insurance coverage, the uninsured have much less access to necessary medical care. They are less likely to see a physician in a year, less likely to get their young children adequately immunized, less likely to receive prenatal care in the first trimester of pregnancy, less likely to have their blood pressure checked, and only half as likely 10 see a physician within 30 days if they have serious symptoms, such as persistent high fever, nausea, or bleeding (Davis \& Rowland, 1983; Freeman, 1987; Freeman et al., 1987).

Second, reduced access to medical care due to lack of insurance coverage may contribute to a severe decline in individuals" health status. Research studies have found that pregnant women and their children and persons with chronic illness are especially at 
risk (Lurie et al., 1984; Lurie et al., 1986;

Braverman et al., 1989).

Finally, although the uninsured get less care than the insured population, everyone pays for care that the uninsured do receive. When the uninsured need urgent care, they usually go to hospitals and clinics. Uncompensated care (bad debts and charity care, mainly for the uninsured) cost hospitals in California, for example, $\$ 975$ million in fiscal year 1985-86 - 49 percent more than in 1981-82, after adjusting for inflation (Sofaer et al., 1990). Charity care cost U.S. hospitals more than $\$ 8$ billion in 1988. Individual and business taxpayers shoulder the financial burden of uncompensated care provided by public hospitals, but these public facilities remain depressingly underfunded, understaffed, and ill equipped to meet this population's needs for medical care (Brown \& Dallek, 1990; Baker et al., 1991; Bindman et al., 1991).

Employers and employees pay for much of the uncompensated care provided by private hospitals. That is, the costs of this care that are not paid out-of-pocket by the patient are shifted to the bills of insured patients, mainly employees of firms that do not provide health benefits. But as such "cost-shifting" has become more difficult over the last few years because employers are demanding discount rates from hospitals, more and more private hospitals have found ways to keep out uninsured patients. Hospitals in many cities throughout the country have sporadically closed their emergency rooms, others have downgraded them permanently, shutting their emergency room doors to emergency rescue ambulances, and many have closed their trauma centers. These actions affect the entire community - people with insurance as well as the uninsured.

\section{RISING HEALTH CARE COSTS}

The other major health care financing problem that plagues the United States is the rapid increase in expenditures for medical care. Health care in the United States has been consuming an ever greater share of our economic resources, from 6 percent of our gross national product in 1965 to an estimated 14 percent in 1992 (Levit et al., 1991; International Trade Administration, 1992). Part of the increase in total expenditures is due to the rapid increase in the costs and prices of medical care, which have been growing at a faster rate than inflation in the rest of the economy. Much of this increase is due to an increasing "intensity" of services provided to each patient, many of which are neither necessary nor effective.

The United States spends a 50 percent greater share of its GNP on health care than any other country in the world. Measured in U.S. dollars per capita, the United States

FIGURE 8. Per Capita Health Spending, Selected OECD Countries, 1989

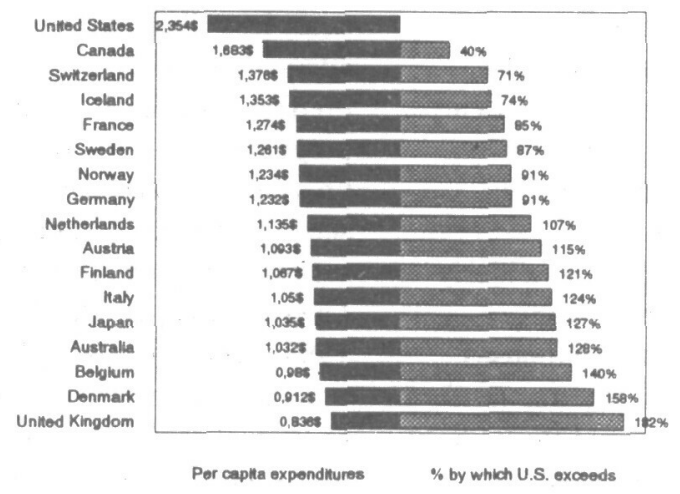


spends 40 percent more than Canada, the second most expensive health system, which covers its entire population through a universal government-run, tax-funded health insurance program in each province (Figure 8) (Schieber \& Poullier, 1991).

\section{Does the United States Get Adequate Value for its Higher Spending?}

Despite greater per capita health care spending, health indicators in the United States demonstrate that it should be getting more for its money. Many less developed countries have lower infant mortality and as good or better life expectancy than the United States. Nineteen other industrialized countries, for example, had lower infant mortality rates in 1987 than the United States. Although medical care contributes less to determining whether people are healthy or sick than do the social and physical environment - such as financial resources, living and working conditions, and culture - as well as personal lifestyle, many types of preventive and curative care have been shown to make a significant and important difference in determining who lives and who dies.

One reason the United States gets less value than it should for the amount it spends on medical care is that more of its health dollars are spent on administration than in other countries. In the United States, 1,500 separate private health plans and an estimated 175,000 self-insured employer plans (McDonnell et al., 1986) compete with one another for enrollees, each bearing substantial marketing costs, analyzing the financial risks of applicants, negotiating fees with individual doctors and hospitals, scrutinizing clinical decisions of physicians, and processing individual bills and claims from health care providers and enrollees. During the 1970s and 1980s, administrative costs took a rapidly increasing share of total health care spending (Levit et al., 1989). The costs of administering health insurance are about 1 percent of total program expenditures in the public Canadian insurance system, about 3 percent of total costs in the United States public Medicare program, and about 11 to 12 percent for private insurance plans in the United States (U.S. General Accounting Office, 1991). These insurance overhead costs do not include the much higher administrative costs of U.S. doctors and hospitals for billing and collecting from a fragmented insurance and payment system (Woolhandler \& Himmelstein, 1991). Higher administrative costs seem to be a corollary of a privatized health care financing system.

The fragmentation of "third-party" payers has prevented payers from negotiating collectively and effectively with hospitals and the medical profession. Only the federal Medicare program has a sufficient share of the market to give it substantial clout in reimbursement policy, enabling it to innovate payment reforms for hospitals and doctors that have had an impact on all payers, public and private alike. Until very recently even the Medicare program reimbursed hospitals their costs for all services performed and paid doctors their "usual and customary" fees for all covered services. Medicare's change in hospital reimbursement to a prospective pricing policy per admission, with the payment based on classification of the patient into one of several hundred diagnosis-related groups (DRGs), has influenced hospital care and expenditures under all third-party payers (Lave, 1989). Payment for physician services is now also being reformed by Medicare, to a fixed-fee schedule designed with financial incentives to encourage more primary care at the expense of procedure-oriented specialists (Iglehart, 1990; Ginsburg et al., 1990).

Although Medicare reimbursement reforms have influenced other payers, competing private health insurance plans have themselves relied on competition among hospitals and doctors to negotiate prices individually. This strategy of a private competitive solution to the cost problem has divided payers from one another and left health services and medical care costs virtually uncontrolled.

\section{Health Insurance has Become Unaffordable for Many}

Higher medical care costs mean higher premiums. As costs of care escalated, health 
benefit costs rose accordingly. Between 1977 and 1987 , average premium contributions for employment-based health benefits per person covered increased 49 percent in inflation-adjusted dollars, from $\$ 1,111$ to $\$ 1,656$ (both figures are in 1987 dollars) (DiCarlo \& Gabel, 1989). Every year, employers get hit with substantial double-digit percentage increases in the costs of health benelits (Gabel et al., 1989; Medical Benefits, 1989).

Small firms have been hit very hard by rising health care costs and insurance premiums. Certainly one factor that contributes to the high cost of insurance for individual firms and employer trusts is experience rating, which has isolated smaller risk groups and exposed them to ever escalating rates. (Under "experience rating", the insurer bases the premium in part on the costs of health benefits used by that covered group. This is distinguished from "community rating, "in which the insurer averages the costs of all covered persons as one "risk group", rather than considering the experience of particular subgroups.)

Rising costs have made it difficult for small businesses to purchase insurance. The health insurance market for small groups is drying up throughout the country: since 1988, at least 34 insurers have stopped selling group policies to small businesses in California (Reich, 1989; White, 1990). Finding health insurance for small groups in which one or more members have a preexisting medical condition is difficult for even the most dedicated insurance broker. Moreover, as more insurers move from community to experience rating, employers have seen their health insurance premiums skyrocket.

Employers who do provide insurance have responded to rising health benefits costs by encouraging or forcing their employees to join managed-care plans. Employers also have shifted more of the costs of coverage to employees by increasing required cost sharing for premiums and for medical care (Short, 1988; Jensen et al., 1987). Employers' increasingly desperate attempts to control their costs by altering formerly generous health benefits is a major source of conflict in labor-management relations, and has become a main factor in nearly 80 percent of all strikes (Service Employees International Union, 1990). Despite these efforts to control their own costs, many employers are at their wits end. As the president of the California Council of Employer Health Care Coalitions has said, "We have tried a lot of things utilization review, case management, cost sharing with employees, health maintenance organizations, preferred provider organizations, hospices - and costs are still going up 20 to 30 to 40 percent" (Holzman, 1989).

These cost increases have extracted a greater share of workers' earnings and of corporate profits. Between 1965 and 1989, the cost of health benefits has grown from 2 percent of wages and salaries to 8 percent (Figure 9). And it has jumped from 8 percent of pre-tax corporate profits to 56 percent (Figure 10). (Author's analysis of unpublished data from the Health Care Financing Administration.) The financial losses inflicted on business and labor, together with increasing labor-management conflicts and strikes over health benefits, have pushed political pressure for health care reform to an all-time high.

\section{SOLVING THE PROBLEMS: PUBLIC POLICY OPTIONS}

These two healti care financing problems are inextricably linked. A large and growing uninsured population has little access to necessary medical care. When they do get care, the uninsured add to the hospital bills, insurance premiums and taxes of others. Universal coverage of the population would provide more equitable access to health care and end uncompensated-care cost shifting to employers, employees, and government.

Rising health care costs, the second major health care financing problem, are straining the economic resources of employers, workers and their families, as well as all levels of government. The high costs of health care and health insurance make it increasingly difficult for small employers and low-income people 
FIGURE 9. Business Health Benefits Spending as Percent of Wages and Salaries, U.S., 1965-1989

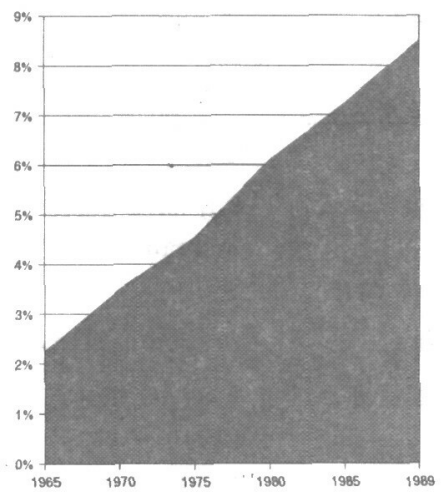

Source: Health Care Financing Administration data author's analysis

FIGURE 10. Business Health Benefits Spending as Percent of Corporate Profits, U.S., 1965-1989

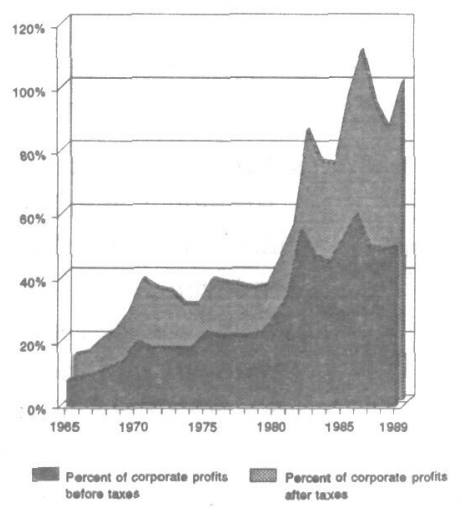

\section{Source: Health Care Financing Administration data author's analysis}

to pay for health benefits. This problem, like the problem of insurance coverage, can be solved most effectively by major reforms in the health care financing system.

The approaches to the problem now being considered range from incremental, targeted strategies - proposals that would provide coverage for some groups of the uninsured to strategies that would completely reform the financing of health care. These restructuring proposals would provide insurance to the entire population by completely reforming the health insurance market or by establishing a universal health services financing program. The variety of reform strategies are discussed below and compared in Table 1 .

\section{Encouraging or Requiring Employers to Provide Coverage}

Some states and private groups, hoping to avoid enacting mandatory programs, have been experimenting with tax credits to encourage employers to cover their uninsured employees. Small employers" participation is influenced by the very factors that now discourage them from providing this fringe benefit - low profit margins and the high cost of insurance (Small Business Administration) - adding up to a competitive disadvantage for those who might add to their products or services the increased labor costs due to health benefits. Few small employers 
TABLE 1. Comparison of Reform Strategies: Advantages and Disadvantages

\begin{tabular}{|c|c|c|c|}
\hline & $\begin{array}{l}\text { Voluntary and } \\
\text { Employer } \\
\text { Mandate }\end{array}$ & "Play or Pay" & $\begin{array}{l}\text { National } \\
\text { Health } \\
\text { Insurance }\end{array}$ \\
\hline Employment-Based? & Yes & Yes & No \\
\hline Population Coverage & Some left out & $\begin{array}{l}\text { All have access to } \\
\text { insurance }\end{array}$ & All are covered \\
\hline $\begin{array}{l}\text { Coverage of Low-Income } \\
\text { Population }\end{array}$ & $\begin{array}{l}\text { Separate } \\
\text { programs/plans }\end{array}$ & $\begin{array}{l}\text { Separate } \\
\text { programs/plans }\end{array}$ & $\begin{array}{l}\text { One universal } \\
\text { program for all }\end{array}$ \\
\hline Revenue Sources & Highly regressive & $\begin{array}{l}\text { May be more } \\
\text { progressive }\end{array}$ & $\begin{array}{l}\text { Much more } \\
\text { progressive }\end{array}$ \\
\hline Cost Containment & None or very little & Moderate, but complex & $\begin{array}{l}\text { Effective and } \\
\text { less complex }\end{array}$ \\
\hline Allocation of Resources & Market only & Market only & $\begin{array}{l}\text { Planning and } \\
\text { market }\end{array}$ \\
\hline Accountability & Market control & $\begin{array}{l}\text { Market plus some } \\
\text { added regulation }\end{array}$ & $\begin{array}{l}\text { Direct political } \\
\text { control plus } \\
\text { market }\end{array}$ \\
\hline
\end{tabular}

are buying into such programs because the cost remains high, for both employer and employee, and because participation remains voluntary. Most of the tax credits for such programs go to employers who are already providing health benefits. In the end, relatively few of the uninsured can be expected to participate in and benefit from these voluntary private insurance programs (Brown \& Dallek, 1990). Nevertheless, the Bush administration, seeking to avoid any mandates that business opposes, has adopted tax credits as its main strategy to extend coverage to the uninsured (The President, 1992).

The most dramatic incremental policy option that is being considered is to require employers to provide health benefits to their workers. The high cost of government-subsidized health coverage programs has encouraged legislators in many states and members of the Congress to propose laws that would mandate employers to provide coverage to their employees and dependents. This strategy would place the full cost of such health insurance on employers and their workers, a completely privatized solution to the uninsured.

Employer mandate proposals, however, would not control health care costs for employers, employees or others. Rather, they would impose a significant cost on small employers and their employees, and they offer no reason for optimism that the double-digit inflation in health care premiums experienced by large as well as small employers would be restrained. Employers, together with their employees, are very frustrated by their inability to control the costs of their health benefits - and they want some relief. Because of its impact on small businesses and general business opposition to government regulation, business groups have heavily attacked employer mandate proposals.

\section{"Play or Pay" Reforms}

A variation on the employer-mandate approach is the "play or pay" strategy (U.S. Bipartisan Commission on Comprehensive Health Care, 1990; Enthoven \& Kronick, 1989; Enthoven \& Kronick, 1991). Designed to ameliorate the impact of the requirement on small firms with low profit margins, "play or pay" would require all employers either to 
provide health benefits or to pay a special health care payroll tax, in most proposals set lower than the cost of purchasing health insurance. With the revenues from this and other taxes, the government would provide coverage in a "pay" program or purchase it for otherwise uninsured people from contract health plans. Although only Massachusetts and Oregon have enacted "play or pay" programs, but not yet implemented them, many states are considering such legislation (Brown \& Dallek, 1990). Several proposals have been introduced into the Congress, including one by the Senate Democratic leadership (U.S. Senate, 1991).

However, the "play or pay" strategy would require heavy government subsidies to make it affordable to low-income workers and low-profit employers. If employers with higher risk workers dump their bad risks into the "pay" program, the need for subsidies would rise dramatically. This tendency toward increasing public-sector costs due to the dumping of bad risks is a threat to any mixed public-private financing system.

"Play or pay" proposals almost all include efforts to prevent some of the insurance industry's most egregious marketing and underwriting practices, particularly those inflicted on small firms. By requiring guaranteed renewal of policies, limiting or prohibiting exclusions of coverage for medical conditions, and limiting the range of premiums that an insurer may charge, these reforms are likely to bring small employer insurance costs closer to those of larger employers.

But "play or pay" proposals' methods to control the rise in medical care costs are weak and very regressive. They almost always rely on market competition between health plans and hospitals and doctors to bring costs under control. Market competition, however, favors large groups with substantial shares of the market. And the competition among health care providers for this business encourages constant over-investment in buildings and equipment, resulting in costly unused capacity, duplication of services, and bankruptcies among many hospitals. Moreover, administrative costs in a competitive, fragmented financing system are very high. These market-oriented proposals also impose heavy cost sharing on enrollees to encourage "cost-conscious" consumer behavior, a tendency that would make health care financing even more regressive (Cantor, 1990).

Finally, "play or pay" strategies would put the poor and mainly lower-income workers in a separate public medical care program.

Despite the improvements this would represent for those now covered by the underfunded Medicaid program, this limited public program would be politically isolated and would remain vulnerable to the budgetary axe (Brown, 1983). Who would join the poor in the public program would depend upon whether only small, usually low-wage employers would be allowed to buy-in, the rate at which the payroll tax is set, and how generous the benefits are. Past experience with Medicaid and other programs restricted to lower-income populations suggests that a new "pay" program would suffer a similar fate of political vulnerability.

The "play or pay" approach would be a halfway reform, ameliorating access and cost conditions caused by the present chaotic collection of very regressively financed private health plans and limited public programs. But it would perpetuate many of the current system's problems. Nevertheless, many analysts and political leaders believe that this approach, compared to more sweeping reforms, is more likely to be enacted, largely because it requires less dramatic changes for insurers, the medical profession and hospitals, and other powerful elements in the present financing system. Despite this optimistic political assessment, business groups have not liked "play or pay" requirements much better than straight employer mandates, and they have fought these proposals in state legislatures and in the Congress with the same intensity.

\section{Universal Coverage Through National Health Insurance}

A more comprehensive reform strategy would establish a universal national health 
insurance program, an approach that long has had a substantial core of political support in the United States but that has been defeated when periodically proposed (Fein, 1986; Starr, 1982). National health insurance (NHI) proposals typically would replace the payment of premiums by employers and individuals to myriad private insurance plans with a government-run health care financing program supported by tax revenues (Fein, 1986; Brc wn, 1988).

These NHI proposals would provide a comprehensive package of benefits covering essentially the entire population in one financing program that would pay for care obtained from independent practitioners and facilities or organized health plans. For example, Rep. "Pete" Stark's (D-Calif.) "Mediplan" proposal, H.R. 650, would extend Medicare-type coverage to all U.S. residents, and Rep. Marty Russo's (D-Ill.) "Universal Health Care Plan," H.R. 1300, would adapt the Canadian national health insurance program to the United States (Himmelstein \& Woolhandler, 1989). Senator Bob Kerrey's (I)-Neb.) "Health USA" proposal, S. 1446, would establish a federal-state NHI program, enabling every resident to enroll in any approved private or state prepaid health plan, with the state health insurance program paying a premium to the enrollee's plan and the plan paying for doctor and hospital services and other covered benefits.

The complete NHI approach has several advantages (see chart below). First, health insurance coverage would no longer depend on or be tied to employment. People would be covered because they are residents of the country, and their coverage would not terminate or change due to changes in their employment status or marital status. A universal financing system that separates coverage from employment, covering the entire population in one program, would provide protection for the poor and other politically less powerful groups, avoiding the inequities of separate, politically vulnerable programs. Even two of the most widely cited authors of the "play or pay" approach acknowledge that an employment-based financing program is not the ideal way to cover a population (Enthoven \& Kronick, 1989).

Second, a public NHI program would permit effective control of health care costs and spending. It would channel most health care dollars through a government financing program with negotiated fee schedules and expenditure targets for doctors and some form of budgeted payment of hospitals. These reimbursement methods have been used effectively by Canada and Germany to control their health care expenditures (Evans et al, 1989; Fuchs \& Hahn, 1990; Kirkman-Liff, 1990; Iglehart, 1991). Such methods also are administratively much simpler and more economical than complex efforts to control utilization by reviewing physicians' clinical decisions.

Third, tax financing would shift the burden of paying for health care from a very regressive system of premiums, which are essentially a flat amount irrespective of income or earnings, to a system that is more progressive, related to ability to pay. Fourth, employers' and employees' liabilities for health care expenditures would be limited and their total health benefits costs greatly reduced to a specified tax. Employers' administrative costs related to their present role of health insurance brokers would be completely eliminated. Fifth, cost shifting between payers would end because providers would receive equal payments for all persons they serve, regardless of the person's source of coverage.

Finally, a tax-funded government financing program would be more accountable than the present financing system that relies on many private insurers. Employer mandates and insurance market reforms leave people vulnerable to the "accountability" of the marketplace, a particularly weak position given the regressiveness of the financing system and the limited choice of plans made available to most employees by their employers. A public financing program could actually expand market accountability by providing a virtually unlimited choice of providers, like the Canadian system, or by giving each person a very wide choice of health plans, as in Senator Kerrey's proposal. 
Of course, any large organization or program, whether a government agency or a private corporation, has a tendency toward bureaucratization and unresponsiveness. But government financing and operating control are subject to the accountability of the democratic political process, while oligopolistic insurance companies are not. A public financing program with expanded market choice and political accountability is thus more likely than the private marketplace to serve society's needs, as well as the interests of private providers and health plans.

Many state legislatures have been considering variations of these basic national NHI and market-reform approaches. The pressure for state action has grown in the absence of leadership from the White House and the Congress. Most advocates see state-level reforms simply as a necessity to come to grips with the growing crises facing almost every state. Many, however, see state health insurance as a way to begin to solve national problems of access and cost containment in those few states that have the economic base and political will to act much as Saskatchewan's leadership in health insurance reform was followed by other Canadian provinces, ultimately leading to a national health program. There is new political momentum behind health care reform in the Congress, reflected in the spate of broad "play or pay" and national health insurance bills as well as in the Bush Administration's recent introduction of its own proposal. It is difficult to say whether the states or the Congress will enact significant reform first.

\section{Public Support for Major Hoalth Ineurance Reform is Growing}

More Americans are very dissatisfied with their health care system, and more likely to support dramatic restructuring, than people in most other industrialized countries. Of 10 industrialized democracies surveyed in a recent study, fewer Americans were satisfied with their system than were the citizens of any other country, despite the fact that the U.S. spends more money per capita on health care. In the United States, 89 percent of respondents believed that fundamental change or complete rebuilding of the nation's health care system is needed (compared, for example, to 69 percent of Britons and 43 percent of Canadians) (Blendon et al., 1990). This view is shared by 91 percent of the chief executive officers of the nation's largest corporations; 73 percent of them say the problems cannot be solved by companies working on their own, that government must take a bigger role in this sector (Cantor, 1991). The leaders of four major national business organizations recently made a joint appeal to the Congress to "do something" about health care costs (Rosenblatt, 1989). And the upset electoral victory of Harris Wofford to a U.S. Senate seat from Pennsylvania, running on a platform calling for national health insurance against a Bush administration official who opposed it, has made it clear that the electorate demands comprehensive health care reform and that politicians who stand in the way may go down to defeat (Hinds, 1991).

Although there is clear and consistent evidence of strong dissatisfaction with the present system, there is less consistent public support for any particular solution (Jajich-Toth \& Roper, 1990). A majority of the public supports a government national health insurance program, while a majority also supports a "play or pay" approach or some other employer mandate, including about a third who support both (Echholm, 1991; Pokorny, 1988; Blendon \& Taylor, 1989). The public opinion polls demonstrate that - driven by fears of potentially ruinous financial losses, inability to obtain care and weariness with the confusion and fragmentation of the present system - people want the problems resolved, but they are poorly educated about the substance and consequences of alternative solutions.

Political pressure is growing rapidly to control health care costs and to extend coverage to the uninsured. At the same time, elected officials fear that new coverage would increase fiscal demands on already strained government tax revenues, and business leaders worry that new programs would add to 
employers labor costs and fuel inflation in health care prices and total expenditures. This apparent political dilemma can be solved by legislation that addresses both problems together in a comprehensive way. There is growing consensus, at least among health policy analysts and many political leaders, that legislation must simultaneously be enacted to provide coverage for the uninsured and underinsured and to control health care spending. But medical industry interest groups have thrown their substantial political weight against reforms that would limit their earnings and profits, as almost any effective cost controls must.

Despite the present impasse, more and more Americans are looking to government either to severely regulate the private insurance industry and operate a very large public health insurance program or to create a universal national health insurance program that would completely replace the present mainly private financing system. It is ironic that, while other countries with predominantly public financing of health services are considering privatizing their health care financing systems, political support for public sector financing and control is rapidly building in the nation with one of the most privatized systems.

\section{RESUMO}

BROWN, E. R. Problemas de Cobertura de Seguridade em Saúde e Serviços nos Estados Unidos da América: Estratégias para Soluções Públicas e Privadas. Cad. Saúde Públ., Rio de Janeiro, 8 (3): 270-286, jul/set, 1992.

É praticamente consenso nos EUA que o atual sistema de saúde está falido. $O$ sistema não foi capaz de controlar o rápido aumento nos custos dos cuidados em saúde (de longe, o mais elevado do mundo), e também não foi capaz de estancar o crescimento da população sem qualquer cobertura de seguro saúde (pelo menos 26 milhões de pessoas). Politicamente, há quase total concordância de que o governo deve prover seguro de saúde a uma parcela bem maior da população do que no passado. $O$ debate político agora centra-se na questāo se este papel expandido do governo deve suplementar o sistema de seguridade privado através de um programa aumentado, de modo a cobrir os que ficam de fora da cobertura oferecida pelo seguro privado, ou substituir o seguro privado por um programa de segurosaúde governamental de abrangência universal, dando cobertura a toda a população.

Palavras-Chave: Seguro de Saúde; Custos de Atendimento à Saúde; Seguro de Saúde

Federal; Financiamento dos Serviços de Saúde

\section{REFERENCES}

BAKER, D. W.; STEVENS, C. D. \& BROOK. R. H., 1991. Patients Who Leave a Public Hospital Without Being Seen by a Physician: Causes and Consequences. Journal of the American Medical Association, 266: 1085-1090.

BINDMAN, A. B.; GRUMBACH, K.; KEANE, D.; RAUCH, L. \& LUCE, J. M., 1991. Consequences of Queuing for Care at a Public Hospital Emergency Department. Journal of the American Medical Association, 266: 10911096.

BLENDON, R. J. \& TAYLOR, D. H., 1989. Views on Health Care: Public Opinion in Three Nations. Health Affairs, 8: 149-157.

BLENDON, R. J.; LEITMAN, R.; MORRISON, L. \& DONELAN, K., 1990. Satisfaction with Health Systems in Ten Nations. Health Affairs, 9: 185-192.

BRAVERMAN, P.; OLIVA, G.; MILLER, M. G.; REITER, R. \& EGERTER, S., 1989. Adverse Outcomes and Lack of Health Insurance Among Newborns in an Eight-County Area of California, 1982 to 1986. New England Journal of Medicine, 321: 508-513.

BROWN, E. R., 1983. Medicare and Medicaid: The Process, Value and Limits of Health Care Reforms. Journal of Public Health Policy, 4: 335-366.

, 1988. Principles for a National Health Program: A Framework for Analysis and Development. Milbank Memorial Found Quarterly, 66: 573-617.

BROWN, E. R. \& DALLEK, G., 1990. State Approaches to Financing Health Care for the Poor. Annual Review of Public Health, 11: 377-400. 
BROWN, E. R.; VALDEZ, R. B.; CUMBERLAND, W.; MORGENSTERN, H.; WANG, C. \& MANN, J., 1991. Health Insurance Coverage of Californians in 1989. Berkeley: California Policy Seminar, University of California.

CANTOR, J. C., 1990. Expanding Health Insurance Coverage: Who Will Pay? Journal of Health Politics, Policy and Law, 15: 755-778.

CANTOR, J. C.; BARRAND, N. L. \& DESONIA, R. A., 1991. Business Leaders' Views on American Health Care. Health Affairs, 10: 98-105.

CONGRESSIONAL RESEARCH SERVICE, LIBRARY OF CONGRESS, 1988. Health Insurance and the Uninsured: Background Data and Analysis. Washington: U.S. Government Printing Office, May 1988.

DAVIS, K. \& ROWLAND, D. 1983. Uninsured and Underserved: Inequities in Health Care in the United States. Milbank Memorial Fund Quarterly, 61: 149-176.

DICARLO, S. \&. GABEL, J., 1989. Conventional Health Insurance: A Decade Later. Health Care Financing Review, 10: 77-89.

ECKHOLM, E., September 26, 1991. Health Benefits Found to Deter Job Switching. New York Times, A1, A12.

ENTHOVEN, A. \& KRONICK, R. 1989. A Consumer-Choice Health Plan for the 1990s. New England Journal of Medicine, 320: 29-37 and 94-101.

1991. Universal Health Insurance Through Insurance Reform. Journal of American Medical Association, 265: 2532-2536.

EVANS, R. G.; LOMAS, J.; BARER, M. L.; LABELLE, R. J.; FOOKS, C.; STODDART, G. L.; ANDERSON, G. M.; FEENY, D.; GAFNI, A.; TORRANCE, G. W. \& THOLL, W. G., 1989. Controlling Health Expenditures - the Canadian Reality. New England Journal of Medicine, 320: 571-577.

FARLEY, P. J., 1985. Who Are the Underinsured? Milbank Memorial Fund Quarterly, 63: 476-503.

FEIN, R., 1986. Medical Care, Medical Costs: The Search for a Health Insurance Policy. Cambridge, MA: Harvard University Press, pp. 33-51.

FREEMAN, H. E., 1987. Americans Report on Their Access to Health Care: The 1986 Robert Wood Johnson Foundation Survey. Los Angeles: Institute for Social Science Research, University of California, Los Angeles.

FREEMAN, H. E.; BLENDON, R. J.; AIKEN, L. H.; SUDMAN, S.; MULLINIX, C. F.; COREY, C. R., 1987. Americans Report on Their Access to Health Care. Health Affairs, 6: 06-18.
FUCHS, V. R. \& HAHN, J. S., 1990. How Does Canada Do It? A Comparison of Expenditures for Physicians' Services in the United States and Canada. New England Journal of Medicine, 323: 884-890.

GABEL, J.; DICARLO, S.; DE LISSOVOY, G. \& FINK, S., 1989. Employer-Sponsored Health Insurance in America: Preliminary Results from the 1988 Survey. Washington, DC: Health Insurance Association of America.

GINSBURG, P. B.; LEROY, L. B.; HAMMONS, G. T., 1990. Medicare Physician Payment Reform. Health Affairs, 9: 178-188.

HIMMELSTEIN, D. U. \& WOOLHANDLER, S., 1989. A National Health Program for the United States: A Physicians' Proposal. New England Journal of Medicine, 320: 102-108.

HINDS, M. DeC., November 7, 1991. Wofford Win Shows Voter Mood Swing. New York Times, A11.

HOLZMAN, D., 1989. Rising Cost of Insuring Workers. Insight, 5: 54-55.

IGLEHART, J. K., 1991. Germany's Health Care System. New England Journal of Medicine, 324: 503-508 and 1750-1756.

, 1990. The New Law on Medicare's Payments to Physicians. New England Journal of Medicine, 322: 1247-1252.

INTERNATIONAL TRADE ADMINISTRATION, U.S. Department of Commerce, 1992. 1992 U.S. Industrial Outlook, Washington, DC, pp. 44-1 to 44-6.

JAJCH-TOTH, C. \& ROPER, B. W., 1990. Americans Views on Health Care: A Study in Contradictions. Health Affairs, 9: 149-157.

JENSEN, G. A.; MORRISEY, M. A. \& MARCUS, J. W., 1987. Cost Sharing and the Changing Pattern of Employer-sponsored Health Benefits. Milbank Memorial Found Quarterly, 65: 521550.

KIRKMAN-LIFF, B. L., 1990. Physician Payment and Cost-containment Strategies in West Germany: Suggestions for Medicare Reform. Journal of Health Politics, Policy and Law, 15: 69-99.

LAVE, J, R,, 1989. The Effect of the Medicare Prospective Payment System. Annual Review of Public Health, 10: 141-161.

LEVIT, K. R.; LAZENBY, C.; LETSCH, S. W. \& COWAN, C. A., 1991. National Health Care Spending, 1989. Health Affairs, 10: 117-130.

LURIE, N.; WARD, N. B.; SHAPIRO, M. F. \& BROOK, R. H., 1984. Termination from Medical: Does It Affect Health? New England Journal of Medicine, 311: 480-484. 
LURIE, N.; WARD, N. B.; SHAPIRO, M. F.; GALLEGO, C.; VAGHAIWALLA, R. \& BROOK, R. H., 1986. Termination of Medi-Cal Benefits: A Follow-up Study One Year Later. New England Journal of Medicine, 314: 1266-1268.

MCDONNELL, P.; GUTTENBERG, A.; GREENBERG, L. \& ARNETT, R. H., 1986. Self-Insured Health Plans. Health Care Financing Review, 8: 1-16.

Medical Benefits, February 28, 1989. Health Care Benefits Survey, 1988. pp. 1-2.

The President's Comprehensive Health Reform Program, Feb. 6, 1992 [Washington, DC: The White House].

POKORNY, G., 1988. Report Card on Health Care. Health Management Quarterly, 10: 3-7.

REICH, K., July 15, 1989. Allstate's Dropping of Small Group Health Coverage Stings Many. Los Angeles Times, Part П, pp. 1, 4.

ROSENBLATT, R. A., November 16, 1989. Business Groups Plead for Health-Care Support. Los Angeles Times, A20.

SCHIEBER, G. J. \& POULLIER, J. P., 1991. International Health Spending: Issues and Trends. Health Affairs, 10: 106-116.

, 1989. Overview of International Comparisons of Health Care Expenditures. Health Care Financing Review, 10: 1-7.

SERVICE EMPLOYEES INTERNATIONAL UNION, 1988. The Hidden Story of Taxpayer Subsidies for Low-Wage Employers. Washington, DC: Service Employees International Union.

, February, 1990. Labor and Management on a Collision Course Over Health Care. Washington, DC.
SHORT, P. F., 1988. Trends in Employee Health Insurance Benefits. Health Affairs, 7: 186-196.

SMALL BUSINESS ADMINISTRATION, 1987. The State of Small Business: A Report of the President. Washington, DC: U.S. Government Printing Office, p. 152.

SOFAER, S.; RUNDALL, T. G. \& ZELLERS, W. L., 1990. Restrictive Reimbursement Policies and Uncompensated Care in Califomia Hospitals, 1981-1986. Hospital and Health Services Administration, 35: 189-206.

STARR, P., 1982. The Social Transformation of American Medicine. New York: Basic Books, pp. 235-289.

U.S. BIPARTISAN COMMISSION ON COMPREHENSIVE HEALTH CARE, 1990. A Call for Action, Final Report. Washington, DC: U.S. Government Printing Office.

U.S. GENERAL ACCOUNTING OFFICE, 1991. Canadian Health Insurance: Lessons for the United States. GAO/HRD-91-90. Washington, DC: U.S. GAO.

U.S. SENATE, 1991. Health America: Affordable Health Care for All Americans. S. 1227. 102d Congress, 1st Session.

WHITE, G., January 29, 1990. The Uninsured: Health Gamble Affects 1 in 5. Los Angeles Times, 1990, pp. A1, A 16.

WOOLHANDLER, S. \& HIMMELSTEIN, D. U., 1991. The Deteriorating Administrative Efficiency of the U.S. Health Care System. New England Journal of Medicine, 324: 1253-1258. 